\title{
OPTIMASI SUHU ANNEALING UNTUK PRIMER g-SSR DAN EST-SSR PADA KACANG HIJAU (Vigna radiata L.)
}

\section{Optimization of Annealing Temperature for Primary g-Ssr And Est-Ssr in Mungbean (Vigna radiata $\mathbf{L}$.)}

\author{
Herman, Lambok Nia Natalya T., Suha Maudina Berampu, Dewi Indriyani Roslim \\ Jurusan Biologi, Fakultas Matematika dan Ilmu Pengetahuan Alam, \\ Universitas Riau, Kampus Bina Widya Km 12,5 Simpang Baru-Pekanbaru-Riau 28293 \\ Email: hermansyahdan@ymail.com dan dewiindriyaniroslim@gmail.com \\ [Diterima: Januari 2017; Disetujui: Februari 2017]
}

\begin{abstract}
Mungbean (Vigna radiata L.) is one of important legume in Indonesia. G-SSR and EST-SSR markers had been widely used in mungbean genetic diversity research. DNA isolation and DNA amplification are required to obtain genetic information about mungbean to obtain accurate data on the genetic diversity of mungbean. This study aims to determine the Temperature of annealing (Ta) of the g-SSR and EST-SSR primer pairs. The total DNA was isolated from young leaves mungbean origin Pelalawan and the eight primer pairs of the g-SSR and EST-SSR were optimized. The optimal Ta for G2436, G3598, G2516, G7472, G0483. G1671, G3302, and G3427 were 50,55 ${ }^{\circ} \mathrm{C}, 51,15^{\circ} \mathrm{C}, 51,25^{\circ} \mathrm{C}$, $51,2^{\circ} \mathrm{C}, 51,6^{\circ} \mathrm{C}, 49,0^{\circ} \mathrm{C}, 49,8^{\circ} \mathrm{C}$, and $52,8^{\circ} \mathrm{C}$ respectively. Meanwhile, the optimal Ta for E51985, $\mathrm{E} 19823$, E24080, E22860, E26637, E16266, E11659, and $\mathrm{E} 10675$ were $52,2^{\circ} \mathrm{C}, 54,4^{\circ} \mathrm{C}$, $52,5^{\circ} \mathrm{C}, 51,25^{\circ} \mathrm{C}, 53,25^{\circ} \mathrm{C}, 54^{\circ} \mathrm{C}, 54,35^{\circ} \mathrm{C}$, and $53,6^{\circ} \mathrm{C}$ respectively.
\end{abstract}

Keywords: EST-SSR, g-SSR, Genetic diversity, Mungbean, Temperature of annealing

\begin{abstract}
ABSTRAK
Kacang hijau (Vigna radiata L.) merupakan salah satu tanaman kacang-kacangan yang cukup penting di Indonesia. Penanda g-SSR dan EST-SSR telah banyak digunakan dalam penelitian keanekaragaman genetik kacang hijau. Tujuan dari penelitian ini adalah untuk menentukan suhu annealing dari primer g-SSR dan EST-SSR pada kacang hijau asal Pelalawan. DNA total diisolasi dari daun muda kacang hijau asal Pelalawan dengan metode CTAB. Optimasi suhu annealing dilakukan pada 8 pasang primer g-SSR dan 8 pasang primer EST-SSR. DNA total yang diisolasi terlihat utuh dan tebal. Suhu annealing yang optimal pada primer G2436, G3598, G2516, G7472, G0483. G1671, G3302, dan $\mathrm{G} 3427$ adalah $50,55^{\circ} \mathrm{C}, 51,15^{\circ} \mathrm{C}, 51,25^{\circ} \mathrm{C}, 51,2^{\circ} \mathrm{C}, 51,6^{\circ} \mathrm{C}, 49,0^{\circ} \mathrm{C}, 49,8^{\circ} \mathrm{C}$, dan $52,8^{\circ} \mathrm{C}$ secara berturut-turut. Suhu annealing yang optimal untuk primer E51985, E19823, E24080, E22860, E26637, E16266, E11659, dan E10675 adalah $52,2^{\circ} \mathrm{C}, 54,4^{\circ} \mathrm{C}, 52,5^{\circ} \mathrm{C}, 51,25^{\circ} \mathrm{C}, 53,25^{\circ} \mathrm{C}, 54^{\circ} \mathrm{C}$, $54,35^{\circ} \mathrm{C}$, dan $53,6^{\circ} \mathrm{C}$ secara berturur-turut.
\end{abstract}

Kata kunci: EST-SSR, g-SSR, Kacang hijau, Keanekaragaman genetik, Suhu annealing

\section{PENDAHULUAN}

Penanda SSR telah banyak digunakan dalam berbagai spesies tanaman sebagai alat molekuler untuk mendeteksi keanekaragaman genetik (Somta et al. 2008). Terdapat dua tipe penanda SSR, yaitu Simple Sequence Repeat (SSR) yang terdistribusi di daerah bukan penyandi yang disebut genomic SSR, sedangkan SSR yang terdistribusi di daerah yang ditranskripsikan disebut genic SSR atau
Expressed Sequence Tag (EST)-SSR (Toth et al. 2000).

Teknik molekuler yang dapat digunakan untuk mengetahui keanekaragaman genotipe suatu tanaman adalah dengan teknik PCR (Polymerase Chain Reaction). PCR merupakan teknik untuk mengamplikasi sekuen DNA secara in vitro. Penggunaan teknik PCR telah diperluas dalam penelitian molekuler sebab, kemampuan untuk mengamplifikasi daerah target pada DNA cetakan membutuhkan waktu yang relatif singkat. Pengulangannya berkisar antara 30-50 
siklus replikasi yang melipat gandakan molekul DNA target pada setiap siklusnya (Innis et al. 1990).

Optimasi suhu dilakukan untuk mendapatkan kondisi PCR yang optimal, sehingga dihasilkan produk PCR. PCR dimulai dengan proses denaturasi yaitu pemisahan dua utas DNA yang saling bergabung (double helix) menjadi utas tunggal DNA dengan menggunakan suhu tinggi. Setelah proses denaturasi kemudian dilanjutkan dengan proses annealing, yaitu penempelan primer pada DNA cetakan. Setelah proses annealing, dilanjutkan dengan proses extension yaitu perpanjangan primer atau sintesis DNA (Wahyudi 2007).

Salah satu faktor yang mempengaruhi keberhasilan amplifikasi adalah suhu annealing. Jika suhu annealing terlalu tinggi maka dapat menyebabkan gagalnya amplifikasi karena tidak terjadi penempelan primer dan jika suhu terlalu rendah maka dapat menyebabkan primer menempel pada sisi lain genom akibatnya DNA yang terbentuk memiliki spesifisitas rendah. Oleh karena itu sangat penting untuk mencari suhu annealing yang optimum (Rybicky 2001).

Salah satu cara yang dapat dilakukan untuk optimasi suhu annealing adalah dengan menggunakan suhu annealing yang berkisar hingga $5^{\circ} \mathrm{C}$ lebih rendah dari Tm (Temperature of melting) pasangan primer (Innis dan Gelfand 1990). Proses annealing memerlukan waktu yang singkat berkisar antara 30 detik atau kurang dari 30 detik jika Ta (Temperature of annealing) dekat dengan $\mathrm{Tm}$ atau kecuali primer tidak terlalu panjang seperti umumnya (Rybicky 2001). Optimasi PCR pada penelitian ini bertujuan untuk menentukan suhu annealing dari primer g-SSR dan EST-SSR.

\section{BAHAN DAN METODE}

Penelitian dilaksanakan pada bulan Oktober 2016 hingga bulan Desember 2016. Penanaman sampel kacang hijau telah dilaksanakan di kebun Jurusan Biologi. Isolasi DNA, elektroforesis dan PCR dilaksanakan di Laboratorium Genetika, Jurusan Biologi, Fakultas Matematika dan Ilmu Pengetahuan Alam, Universitas Riau.

Alat yang digunakan dalam penelitian ini antara lain: alumunium foil, erlenmeyer, gelas beaker, gelas ukur, glove, hot plate, kamera (Olympus SP-500 UZ), kertas parafilm, kulkas/freezer, masker, mesin elektroforesis (Fison Mode FEC 360, Large Horizontal Gel
System), mesin sentrifus, mesin spindown, mesin PCR (Polymerase Chain Reaction), mikropipet berukuran $10 \mu 1,100 \mu \mathrm{l}$, dan $1000 \mu$ l, pinset, rak tabung mikro, spatula, sisir dan cetakan gel agarose, tabung $1,5 \mathrm{ml}$, tabung $0,2 \mathrm{ml}$, tip mikro, UV transiluminator (Wiseuv WUV-M20, Daihan Scientific), dan waterbath.

Bahan yang digunakan pada penelitian ini antara lain: daun muda kacang hijau berumur lima minggu yang berasal dari Kabupaten Pelalawan (Herman et al. 2015), agarose, akuabidestilasi $\left(\mathrm{dH}_{2} \mathrm{O}\right)$, akuades, buffer CTAB $\left(\mathrm{dH}_{2} \mathrm{O} ; 1 \mathrm{M}\right.$ Tris- $\mathrm{HCl} \mathrm{pH} 9 ; 5 \mathrm{M} \mathrm{NaCl} ; 0,5 \mathrm{M}$ EDTA ; $14 \mathrm{M} \beta$-mercaptoetanol ; $2 \%$ CTAB), buffer TE ( $\mathrm{pH} 8$ ), 70\% etanol, etidium bromida, fenol, isopropanol, kloroform, loading dye 6X, Mix PCR (10 X buffer PCR; 2 mM dNTPs; 10 $\mu \mathrm{M}$ Primer R; $10 \mu \mathrm{M}$ Primer F; 5 unit $/ \mu \mathrm{l}$ Taq DNA Polymerase; $\left.\mathrm{dH}_{2} \mathrm{O} ; 100 \mathrm{ng} / \mu \mathrm{l} \mathrm{DNA}\right)$, dan $1 \mathrm{X}$ buffer TBE (Tris ; Boric acid ; EDTA).

Isolasi DNA total dilakukan setelah tanaman kacang hijau berumur lima minggu atau setelah tanaman menghasilkan minimal 5 helai daun. Isolasi DNA total dilakukan menggunakan metode CTAB (Saghai-Maroof et al. 1984) dengan sedikit modifikasi, yaitu dengan cara sampel yang diinkubasi dalam waterbath disentrifus terlebih dahulu kemudian ditambahkan kloroform.

Elektroforesis DNA total dilakukan pada 1,2\% gel agarose dalam 1X buffer TBE (TrisBoric acid-EDTA $\mathrm{pH} 8,0$ ) yang mengandung 5 $\mu \mathrm{g} / \mathrm{ml}$ etidium bromida, setelah itu di-running pada mesin elektroforesis dengan tegangan 190 volt selama \pm 20 menit, kemudian divisualisasikan di atas lampu $U V$ transiluminator dan difoto menggunakan kamera berfilter merek Olympus SP-500 UZ.

Optimasi suhu annealing pada primer g-SSR dan EST-SSR pada 8 pasang primer dilakukan pada berbagai suhu annealing (Tabel 1 dan Tabel 2).

Total volume PCR yang digunakan adalah $25 \mu$ l. Proses PCR diawali dengan tahapan PraPCR pada suhu $94^{\circ} \mathrm{C}$ selama 3 menit dan dilanjutkan sebanyak 35 siklus. Masing-masing siklus terdiri dari tiga tahap, yaitu: denaturasi pada suhu $94^{\circ} \mathrm{C}$ selama 30 detik, annealing disesuaikan dengan masing-masing primer (Tabel 3 dan Tabel 4) selama 45 detik, extension pada suhu $72^{\circ} \mathrm{C}$ selama 1 menit 30 detik. Proses PCR diakhiri dengan Pasca PCR pada suhu $72^{\circ} \mathrm{C}$ selama 10 menit. Optimasi suhu annealing dilakukan pada dua suhu, yaitu rata-rata Tm $5^{\circ} \mathrm{C}$ dan $-3^{\circ} \mathrm{C}$ (Tabel 3 dan Tabel 4 ). 
Elektroforesis produk PCR dilakukan pada 2,5\% gel agarose dalam $1 \mathrm{X}$ buffer TBE (Tris-Boric acid-EDTA pH 8,0) yang mengandung $5 \mu \mathrm{g} / \mathrm{ml}$ etidium bromida, setelah itu di-running pada mesin elektroforesis dengan tegangan 70 volt selama \pm 40 menit, kemudian divisualisasikan di atas lampu $U V$ transiluminator dan difoto menggunakan kamera berfilter merek Olympus SP-500 UZ.

Tabel 1. Delapan pasang primer g-SSR yang digunakan (Chen et al. 2015)

\begin{tabular}{|c|c|}
\hline Pasangan Primer & 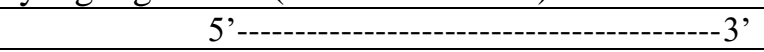 \\
\hline \multirow{2}{*}{ G2436_F/ G2436_R } & F: GACCATTGGTTCAACGAGAAA \\
\hline & R: CCTCAGTCTGGTACCGTAACTACTTC \\
\hline \multirow{2}{*}{ G3598_F/G3598_R } & F: GAGCCATGGGTATGTATAGATTTTT \\
\hline & R: CCTCTCCCTCTTTTTCAGCC \\
\hline \multirow{2}{*}{ G2516_F/G2516_R } & F: GCTTCCACTTTATACATATTACGCA \\
\hline & R: TATGCTTGCAAGAGTGTGGG \\
\hline \multirow{2}{*}{ G1671_F/ G1671_R } & F: CCAGATCAAGAACCTACCACAA \\
\hline & R: GGGACATTAGAGATTCCCCA \\
\hline \multirow{2}{*}{ G3302_F/G3302_R } & F: AAAACTTGTCCAGACCACGG \\
\hline & R: CCCTTTTGTTTGTGGCACTT \\
\hline \multirow{2}{*}{ G3427_F/G3427_R } & F: GCTTCTGCACAACCСТCTTC \\
\hline & R: CCCTACATTTCAGCAACCGT \\
\hline \multirow{2}{*}{ G7472_F/G7472_R } & F: GCGAGCGGAATCAGAATAAC \\
\hline & R: CGTAACCGTAACCTTACCTACTTC \\
\hline \multirow{2}{*}{ G0483_F/ G0483_R } & F: TGTAGAAAAGCAAAAACCAACAAA \\
\hline & R: AGGTAGATGACATGCTCGCC \\
\hline
\end{tabular}

Keterangan: $\mathrm{F}=$ primer forward, $\mathrm{R}=$ primer reverse

Tabel 2. Delapan pasang primer EST-SSR yang digunakan (Chen et al. 2015)

\begin{tabular}{|c|c|}
\hline Pasangan Primer & 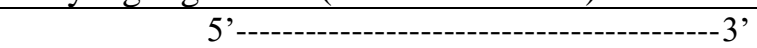 \\
\hline \multirow{2}{*}{ E22860_F / E22860_R } & F: AGCATGGTATAAGAATGAGAGGGT \\
\hline & R: TTTCTTCAAGCTGGGGTGCT \\
\hline \multirow{2}{*}{ E26637_F / E26637_R } & F: AAGCGTGGAAGTGGAGTGAG \\
\hline & R: ACCGACTTAACGTTATTGAAAAGAGG \\
\hline \multirow{2}{*}{ E24080_F / E24080_R } & F: GCTCCCATTCACCATCCCAA \\
\hline & R: TCCGGTTCCTTCCCACAATG \\
\hline \multirow{2}{*}{ E51985_F / E51985_R } & F: GCGATCGAGTCACTCTACGG \\
\hline & R: TCATCCGCCACAACCTCTTC \\
\hline \multirow{2}{*}{ E19823_F / E19823_R } & F: ACAACAAGGATCACCGTCCC \\
\hline & R: TCAGTCTCTCCAGCTCCGAA \\
\hline \multirow{2}{*}{ E16266_F / E16266_R } & F: AGAACCATGCCACGTGACAT \\
\hline & R: GTCCAACCACGCAAACTCAC \\
\hline \multirow{2}{*}{ E11659_F / E11659_R } & F: ACGCTCGAAATATCACCCCC \\
\hline & R: GGGTCTCGAGTTTGTGAGGG \\
\hline \multirow{2}{*}{ E10675_F/E10675_R } & F: GCAGAAGGAAGCTCAAGATCG \\
\hline & R: GCTTCCCACAACTCCCAGAA \\
\hline
\end{tabular}

Keterangan: $\mathrm{F}=$ primer forward, $\mathrm{R}=$ primer reverse

Tabel 3. Kombinasi pasangan primer g-SSR dan suhu annealing

\begin{tabular}{|c|c|c|c|}
\hline \multirow{2}{*}{ Pasangan Primer } & \multirow{2}{*}{ Rata-rata $\operatorname{Tm}\left({ }^{\circ} \mathrm{C}\right)$} & \multicolumn{2}{|c|}{$\mathrm{Ta}\left({ }^{\circ} \mathrm{C}\right)$} \\
\hline & & Tm -5 & Tm -3 \\
\hline G2436_F/ G2436_R & 55,95 & 50,55 & 52,55 \\
\hline G3598_F/ G3598_R & 54,15 & 49,15 & 51,15 \\
\hline G2516_F/ G2516_R & 54,25 & 49,25 & 51,25 \\
\hline G1671_F/ G1671_R & 54,0 & 49,0 & 51,0 \\
\hline G3302_F/ G3302_R & 54,8 & 49,8 & 51,8 \\
\hline G3427_F/ G3427_R & 55,8 & 50,8 & 52,8 \\
\hline G7472_F/ G7472_R & 54,2 & 49,2 & 51,2 \\
\hline G0483_F/ G0483_R & 54,6 & 49,6 & 51,6 \\
\hline
\end{tabular}

Keterangan: $\mathrm{F}=$ primer forward, $\mathrm{R}=$ primer reverse, $\mathrm{Tm}=$ Temperature of melting, $\mathrm{Ta}=$ Temperature of annealing 
Tabel 4. Kombinasi pasangan primer EST-SSR dan suhu annealing

\begin{tabular}{cccc}
\hline \multirow{2}{*}{ Pasangan Primer } & \multirow{2}{*}{ Rata-rata Tm $\left({ }^{\circ} \mathrm{C}\right)$} & Tm -5 & Ta $\left({ }^{\circ} \mathrm{C}\right)$ \\
\cline { 3 - 4 } E22860_F / E22860_R & 56,25 & 51,25 & Tm -3 \\
E26637_F / E26637_R & 56,25 & 51,25 & 53,25 \\
E24080_F / E24080_R & 57,5 & 52,5 & 54,5 \\
E51985_F / E51985_R & 57,2 & 52,2 & 54,2 \\
E19823_F / E19823_R & 57,4 & 52,4 & 54,4 \\
E16266_F / E16266_R & 57,0 & 52,0 & 54,0 \\
E11659_F / E11659_R & 57,35 & 52,35 & 54,35 \\
E10675_F / E10675_R & 56,6 & 51,6 & 53,6 \\
\hline
\end{tabular}

Keterangan: $\mathrm{F}=$ primer forward, $\mathrm{R}=$ primer reverse, $\mathrm{Tm}=$ Temperature of melting, $\mathrm{Ta}=$ Temperature of annealing

\section{HASIL DAN PEMBAHASAN}

\section{Molekul DNA Total Kacang Hijau}

Molekul DNA total yang diperoleh dari isolasi menggunakan metode CTAB (SaghaiMaroof et al. 1984) memiliki pita DNA yang baik dan bagus, yaitu pita yang terlihat jelas, terang dan utuh atau tidak smear (Gambar 1).
Menurut Indriyani (2017), ketebalan suatu pita DNA berbanding lurus dengan kosentrasi DNA, semakin tebal pita DNA yang diperoleh maka semakin tinggi pula kosentrasi DNA. Ukuran pita DNA total yang diperoleh adalah di atas 10.000 bp. Ketebalan pita dapat mempengaruhi amplifikasi DNA, sehingga untuk pita DNA yang tebal perlu dilakukan pengenceran.

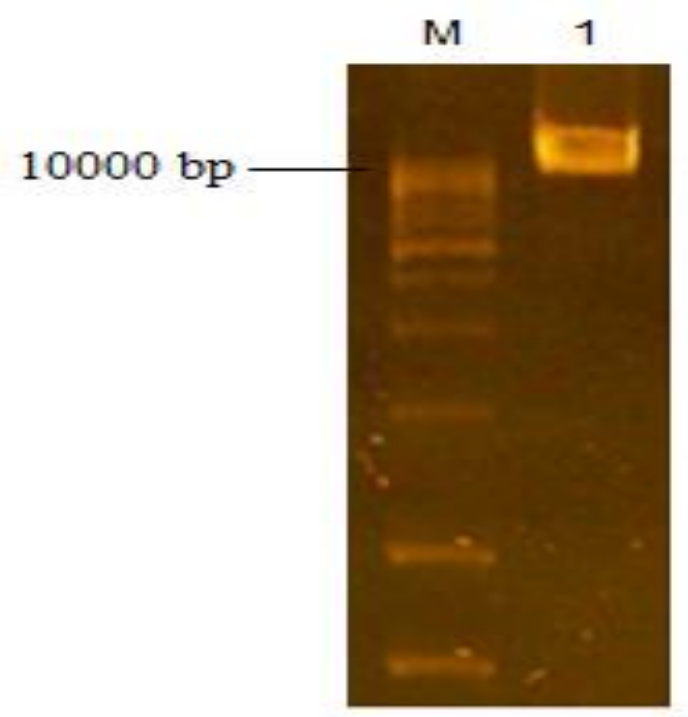

Gambar 1. Molekul DNA total kacang hijau (Keterangan: $\mathrm{M}=$ Marker $1 \mathrm{~kb}$ DNA ladder (ThermoScientific), 1= DNA total kacang hijau asal Kabupaten Pelalawan)

\section{Suhu annealing untuk primer g-SSR}

Optimasi suhu annealing dilakukan pada delapan pasang primer g-SSR (Gambar 2). Visualisasi hasil optimasi primer menggunakan primer G3598 dengan menggunakan suhu annealing dari penurunan suhu melting sebesar $5^{\circ} \mathrm{C}$ diperoleh satu fragmen DNA yang utuh dan tidak smear berukuran 190 bp, sedangkan dengan menggunakan penurunan suhu melting sebesar $3^{\circ} \mathrm{C}$ diperoleh satu fragmen DNA yang utuh dan tidak smear berukuran $180 \mathrm{bp}$. Pada primer G7472 dengan menggunakan suhu annealing dari penurunan suhu melting sebesar $5^{\circ} \mathrm{C}$ diperoleh sebelas fragmen DNA, yaitu satu fragmen di bawah $100 \mathrm{bp}$, tujuh fragmen berukuran 168 bp, 170 bp, 300 bp, 400 bp, 480 bp, $510 \mathrm{bp}, 1000 \mathrm{bp}$ dan tiga fragmen di atas 1000 bp, sedangkan dengan menggunakan penurunan suhu melting sebesar $3^{\circ} \mathrm{C}$ diperoleh sepuluh fragmen DNA, yaitu tujuh fragmen berukuran 170 bp, 300 bp, 400 bp, 480 bp, 510 bp, $600 \mathrm{bp}, 710 \mathrm{bp}$ dan tiga fragmen diatas 1000 bp. Primer G1671 dengan menggunakan suhu annealing dari penurunan suhu melting sebesar $5^{\circ} \mathrm{C}$ dan $3^{\circ} \mathrm{C}$ masing-masing memperoleh satu fragmen DNA yang utuh dan tidak smear 
berukuran 174 bp. Pada primer G3427 dengan menggunakan suhu annealing dari penurunan suhu melting sebesar $5^{\circ} \mathrm{C}$ dan $3^{\circ} \mathrm{C}$ masingmasing memperoleh satu fragmen DNA yang utuh dan tidak smear berukuran $160 \mathrm{bp}$.

Primer G2436 dengan menggunakan suhu annealing dari penurunan suhu melting sebesar $5^{\circ} \mathrm{C}$ dan $3^{\circ} \mathrm{C}$ masing-masing memperoleh satu fragmen DNA yang utuh dan tidak smear berukuran 100 bp. Primer G0483 dengan menggunakan suhu annealing dari penurunan suhu melting sebesar $5^{\circ} \mathrm{C}$ diperoleh empat fragmen DNA berukuran 120 bp, 220 bp, 690 bp, 890 bp, sedangkan dengan menggunakan penurunan suhu melting sebesar $3^{\circ} \mathrm{C}$ diperoleh satu fragmen DNA yang utuh dan tidak smear berukuran 120 bp. Primer G2516 dengan menggunakan suhu annealing dari penurunan suhu melting sebesar $5^{\circ} \mathrm{C}$ tidak terjadi amplifikasi, sedangkan dengan menggunakan suhu annealing dari penurunan suhu melting sebesar $3^{\circ} \mathrm{C}$ diperoleh satu fragmen DNA yang utuh dan tidak smear berukuran $120 \mathrm{bp}$.

Primer G3302 dengan menggunakan suhu annealing dari penurunan suhu melting sebesar $5^{\circ} \mathrm{C}$ dan $3^{\circ} \mathrm{C}$ masing-masing memperoleh satu fragmen DNA yang utuh dan tidak smear berukuran $150 \mathrm{bp}$.

\begin{tabular}{|c|c|c|c|c|c|c|c|c|}
\hline Primer & G3598 & G7472 & G1671 & G3427 & G2436 & G0483 & G2516 & G3302 \\
\hline Tm-x & Tm-5 Tm-3 & Tm-5 Tm-3 & $\mathrm{Tm}-5 \mathrm{Tm}-3$ & $\mathrm{Tm}-5 \quad \mathrm{Tm}-3$ & Tm-5 Tm-3 & $\mathrm{Tm}-5 \mathrm{Tm}-3$ & $\mathrm{Tm}-5 \mathrm{Tm}-3$ & $\mathrm{Tm}-5 \mathrm{Tm}-3$ \\
\hline $\mathrm{Ta}\left({ }^{\circ} \mathrm{C}\right)$ & $49,15 \quad 51,15$ & $49,2 \quad 51,2$ & $49,0 \quad 51,0$ & $50,8 \quad 52,8$ & $50,5552,55$ & $49,6 \quad 51,6$ & $49,2551,2$. & $49,8 \quad 51,8$ \\
\hline
\end{tabular}
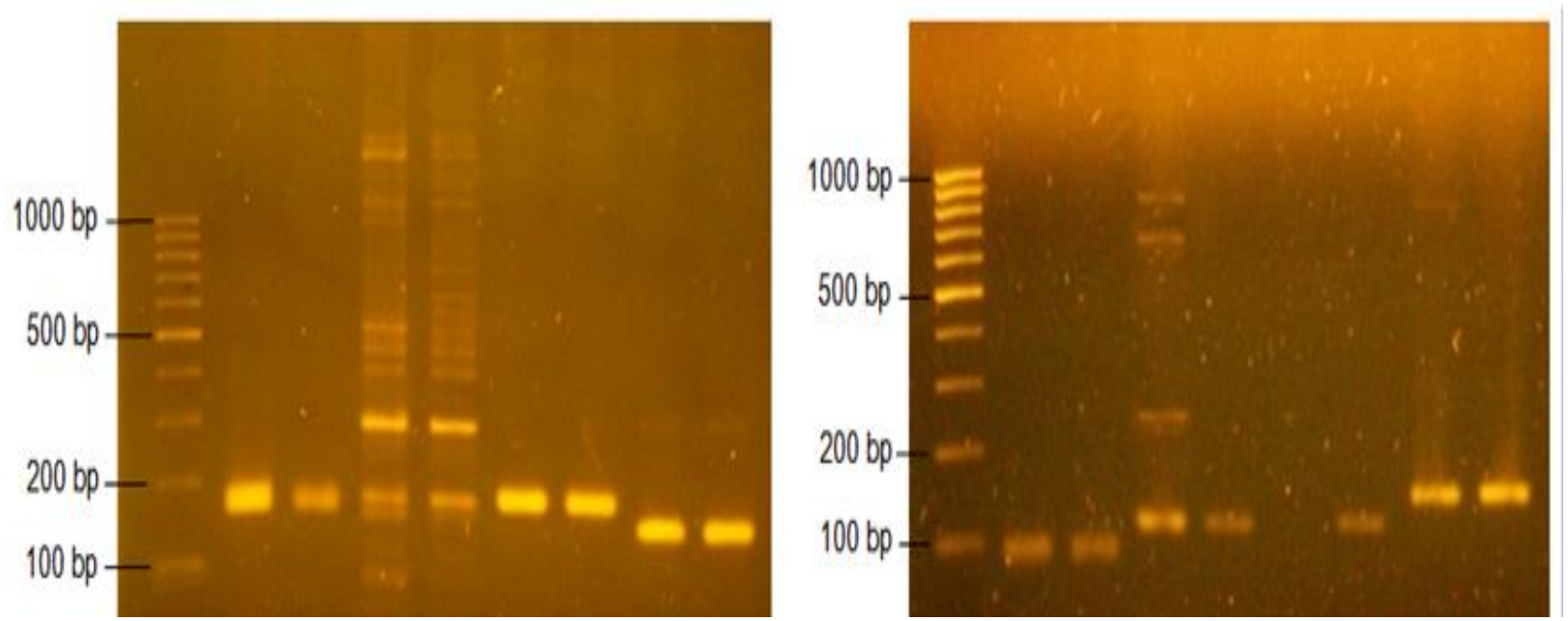

Gambar 2. Profil pita DNA hasil optimasi suhu annealing 8 pasang primer g-SSR pada kacang hijau. Keterangan: $(\mathrm{Tm})=$ suhu melting,$(\mathrm{Ta})=$ suhu annealing .

Berdasarkan hasil di atas, maka suhu annealing yang optimal dari setiap primer
g-SSR untuk mengamplifikasi DNA kacang hijau disajikan pada Tabel 5.

Tabel 5. Suhu annealing yang optimal untuk 8 primer g-SSR

\begin{tabular}{ccc}
\hline No. & Primer & Suhu annealing yang optimal $\left({ }^{\circ} \mathrm{C}\right)$ \\
\hline 1. & G2436 & 50,55 \\
2. & G3598 & 51,15 \\
3. & G2516 & 51,25 \\
4. & G7472 & 51,2 \\
5. & G0483 & 51,6 \\
6. & G1671 & 49,0 \\
7. & G3302 & 49,8 \\
8. & G3427 & 52,8 \\
\hline
\end{tabular}




\section{Suhu annealing untuk primer EST-SSR}

Hasil optimasi suhu annealing pada 8 pasang primer EST-SSR disajikan pada Gambar 3. Visualisasi hasil optimasi primer menggunakan primer E51985 dengan menggunakan suhu annealing dari penurunan suhu melting sebesar $5^{\circ} \mathrm{C}$ menghasilkan 3 pita yang berukuran $300 \mathrm{bp}, 600 \mathrm{bp}$ dan $700 \mathrm{bp}$, sedangkan dengan menggunakan penurunan suhu melting sebesar $3^{\circ} \mathrm{C}$ hanya menghasilkan 1 pita yag berukuran $300 \mathrm{bp}$. Pita yang berukuran 300 bp pada penurunan suhu melting sebesar $5^{\circ} \mathrm{C}$ lebih tebal daripada pita pada penurunan suhu melting sebesar $3^{\circ} \mathrm{C}$. Pada primer E19823 dengan menggunakan suhu annealing dari penurunan suhu melting sebesar $5^{\circ} \mathrm{C}$ dan $3^{\circ} \mathrm{C}$ menghasilkan sebuah pita yang berukuran 200 bp. Pita pada penurunan suhu melting sebesar $3^{\circ} \mathrm{C}$ lebih tebal daripada pita pada penurunan suhu melting sebesar $5^{\circ} \mathrm{C}$. Pada primer E11659 dengan menggunakan suhu annealing dari penurunan suhu melting sebesar $5^{\circ} \mathrm{C}$ dan $3^{\circ} \mathrm{C}$ menghasilkan sebuah pita yang yang utuh dan tidak smear berukuran 150 bp. Pada primer E10675 dengan menggunakan suhu annealing dari penurunan suhu melting sebesar $5^{\circ} \mathrm{C}$ dan $3^{\circ} \mathrm{C}$ menghasilkan sebuah pita yang yang utuh dan tidak smear berukuran $150 \mathrm{bp}$.

Visualisasi hasil optimasi primer menggunakan primer E16266 dengan menggunakan suhu annealing dari penurunan suhu sebesar $5^{\circ} \mathrm{C}$ dan $3^{\circ} \mathrm{C}$ menghasilkan pita berukuran 290 bp. Pada primer E24080 dengan menggunakan suhu annealing dari penurunan suhu melting sebesar $5^{\circ} \mathrm{C}$ dan $3^{\circ} \mathrm{C}$ menghasilkan pita berukuran 290 bp. Pita yang berukuran 290 bp pada penurunan suhu melting sebesar $3^{\circ} \mathrm{C}$ lebih tebal daripada pita pada penurunan suhu melting sebesar $5^{\circ} \mathrm{C}$. Pada primer E26637 dengan menggunakan suhu annealing dari penurunan suhu melting sebesar $5^{\circ} \mathrm{C}$ dan $3^{\circ} \mathrm{C}$ menghasilkan pita berukuran 250 bp. Pita pada penurunan suhu melting sebesar $5^{\circ} \mathrm{C}$ lebih tebal daripada pita pada penurunan suhu melting sebesar $3^{\circ} \mathrm{C}$. Pada primer E22860 dengan menggunakan suhu annealing dari penurunan suhu melting sebesar $5^{\circ} \mathrm{C}$ dan $3^{\circ} \mathrm{C}$ menghasilkan pita berukuran 250 bp. Pita pada penurunan suhu melting sebesar $3^{\circ} \mathrm{C}$ lebih tebal daripada pita pada penurunan suhu melting sebesar $5^{\circ} \mathrm{C}$.

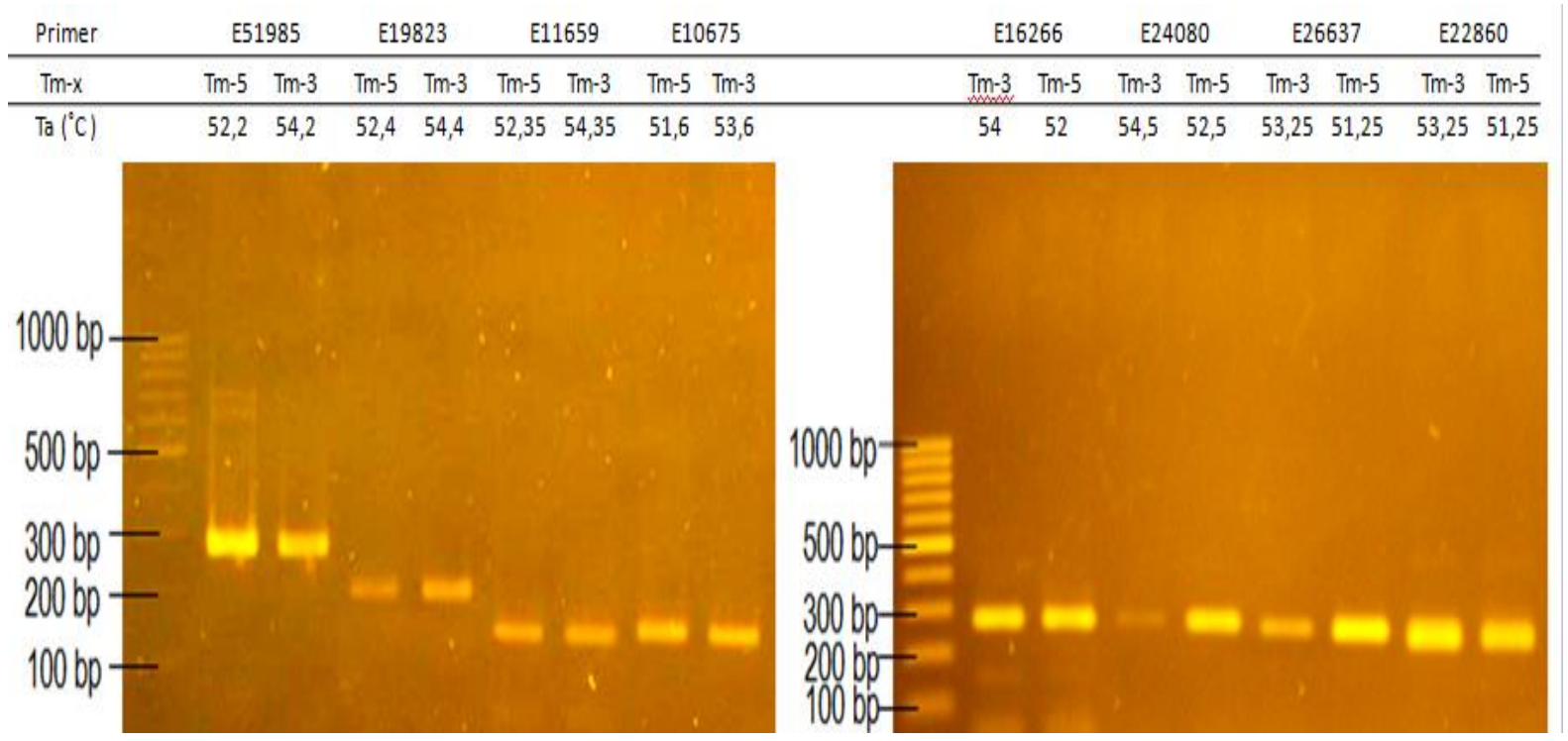

Gambar 3. Profil pita DNA hasil optimasi suhu annealing 8 pasang primer EST-SSR pada kacang hijau. Keterangan: $(\mathrm{Tm})=$ suhu melting, $(\mathrm{Ta})=$ suhu annealing .

Berdasarkan hasil di atas, maka suhu annealing yang optimal dari setiap primer EST-
SSR untuk mengamplifikasi DNA kacang hijau disajikan pada Tabel 6. 
Tabel 6. Suhu annealing yang optimal untuk 8 primer EST-SSR

\begin{tabular}{ccc}
\hline No. & Primer & Suhu annealing yang optimal $\left({ }^{\circ} \mathrm{C}\right)$ \\
\hline 1. & E519885 & 52,2 \\
2. & E19823 & 54,4 \\
3. & E24080 & 52,5 \\
4. & E22860 & 51,25 \\
5. & E26637 & 53,25 \\
6. & E16266 & 54 \\
7. & E11659 & 54,35 \\
8. & E10675 & 53,6 \\
\hline
\end{tabular}

\section{KESIMPULAN}

Suhu annealing yang optimal untuk primer G2436, G3598, G2516, G7472, G0483. G1671, G3302, dan $\mathrm{G} 3427$ adalah $50,55^{\circ} \mathrm{C}$, $51,15^{\circ} \mathrm{C}, 51,25^{\circ} \mathrm{C}, 51,2^{\circ} \mathrm{C}$, dan $51,6^{\circ} \mathrm{C}, 49,0^{\circ} \mathrm{C}$, $49,8^{\circ} \mathrm{C}$, dan $52,8^{\circ} \mathrm{C}$ secara berturut-turut. Suhu annealing yang optimal untuk primer E51985, E19823, E24080, E22860, E26637, E16266, E11659, dan E10675 adalah $52,2^{\circ} \mathrm{C}, 54,4^{\circ} \mathrm{C}$, $52,5^{\circ} \mathrm{C}, 51,25^{\circ} \mathrm{C}, 53,25^{\circ} \mathrm{C}, 54^{\circ} \mathrm{C}, 54,35^{\circ} \mathrm{C}$, dan $53,6^{\circ} \mathrm{C}$ secara berturur-turut. Suhu annealing yang tepat dapat menghasilkan pita yang baik dalam visualisasi hasil optimasi primer sehingga dapat digunakan untuk mendapatkan fragmen DNA target dengan menggunakan teknik PCR.

\section{UCAPAN TERIMAKASIH}

Penulis mengucapkan terima kasih kepada Direktorat Riset dan Pengabdian Masyarakat Dirjen Penguatan Riset dan Pengembangan Kementerian Riset, Teknologi, dan Pendidikan Tinggi Republik Indonesia yang telah memberikan dukungan dana penelitian Hibah Unggulan Perguruan Tinggi atas nama Herman, M.Sc, Ph.D.

\section{DAFTAR PUSTAKA}

Chen H, Qiao L, Wang L,Wang S, Blair MW, Cheng X. 2015. Assesment of Genetic Diversity and Population Structure of Mungbean (Vigna radiata L.) Germplasm using EST-Based and Genomic SSR Markers. Gene.566: 175-183.

Herman, Dewi R, Roslim DI, Rasyad A. 2015. Genetic Diversity Analysis of Mungbean (Vigna radiata L.) from Riau Province based on Morphological and Agronomic
Characters. Di dalam: Proceedings SABRAO $13^{\text {th }}$ Congress and International Conference; Bogor, 14-16 September 2015. Bogor: SABRAO.

Indriyani R. 2017. Keanekaragaman Genetik Padi (Oryza Sativa L.) Lokal Sumatera Utara dengan Menggunakan Penanda Simple Sequence Repeat (SSR) [skripsi]. Medan: Departemen Biologi FMIPA USU.

Innis MA, Gelfand DH, Sninsky JJ and White TJ. 1990. PCR Protocols, A Guide to Methods and Applications. New York: Academic Press Inc.

Rybicky EP. 2001. PCR Primer Design and Reaction Optimisation In Molecular Biology Techniques Manual. South Africa: Departement of Microbiology University Cape Town.

Saghai-Maroof MA, Soliman KM, Jorgensen RA, Allard RW. 1984. Ribosomal DNA Spacer-Length Polymorphisms in Barley: Mendelian Inheritance, Chromosomal Location, and Population Dynamics. PNAS. 81:8014-8018.

Somta P, Musch W, Kongsamai B, Chanprame S, Nakasathien S, Toojinda T, Sorajjapinun W, Seehalak W, Tragoonrung S, Srinives P. 2008. New Microsatellite Markers Isolated From Mungbean (Vigna radiataL.) Wilczek). Mol. Ecol. Resour. 8, 1155-1157.

Toth G, Gapsari Z, Jurka J. 2000. Microsatellites in Different Eukaryotic Genome, Survey and Analysis. Genome Res 10:1967-1981.

Wahyudi TH. 2007. Pengaruh Suhu Annealing dan Jumlah Siklus yang Berbeda Pada Program PCR Terhadap Keberhasilan Isolasi dan Amplifikasi mtDNA Ikan Patin (Pangasius hypothalamus) [Skripsi]. Bogor: ITB. 
